\title{
Acute Infective Polyneuritis
}

National Cancer Institute

\section{Source}

National Cancer Institute. Acute Infective Polyneuritis. NCI Thesaurus. Code C26790.

An acute inflammatory process affecting the peripheral nervous system and nerve roots.

It results in demyelination. It is often caused by an acute viral or bacterial infection. 